総 説

\title{
卵白蛋白質の分子構造と多面的機能に関する 基礎及び応用研究
}

(平成 13 年度日本食品科学工学会賞)

\author{
渡 邊 乾 二 ${ }^{* * *}$ \\ Basic and Applied Studies on Molecular Structure and Various \\ Functions of Egg Protein \\ Kenji Watanabe ${ }^{*, * *}$ \\ ${ }^{*}$ Faculty of Agriculture, Gifu University, Yanagido 1-1, Gifu 501-1193, Japan \\ **(Present address: Faculty of Agriculture, Tokyo University of Agriculture, \\ Funako 1737, Atsukishi, Kanagawa 243-0034, Japan)
}

食品には栄養, 嘹好（風味と食感）及び生理学上の機 能があり，それらは食品を構成している成分の分子構造 の特性に依存している，筆者は食品成分の分子構造との 関係のもとに, 食品加工処理（特に熱, 凍結, 発醉と醉 素処理）を機能発現手段としてとらえ，内在する多面的 な機能を具現化した食品素材の開発につき，基礎から応 用までの研究を展開した，今回の受賞の対象となった研 究項目は，次の上うに分けられる. (1)食品の風味とそれ に関与する成分の解析, (2) 食品蛋白質の分子構造と生体 調節機能の解析及び応用, (3) 食品の凍結濃縮法の開発之 新規凍結物性の創製, (4) 食品脂質の栄養・生理学的機能 の改変・向上への試み一特にコレステロールの低减化 法，及び酸化防止剂の開発一である。筆者は最近の研究 では特に卵白がすつ食品素材としての価値を解析するべ く, 分子レベルでの卵白蛋白質の構造之機能（生体調節 機能と食品物性）につき検討してきた。本稿では，紙面 の都合上(2)の内のその卵白蛋白質に関する二つの話題 にっいて略述する。

\section{1. オボムチンの分子構造と生体調節機能”}

一般的に，ムチンは糖含量が $40 \sim 60 \%$ の粘液質の糖 蛋白質であり, 動物の鼻腔, 顎下腺, 気道, 胃, 腸, 子 宮等の粘膜表層にゲルとして存在し, 物理的傷害や消化 酵素からの粘膜の保護並びに潤滑剤として機能してい る2).さらに, 細菌をはじめとする微生物をトラップし, 排除する機能も有している. 最近になって，I型膜貫通 蛋白質であるMUC1 では, その糖鎖の一部による接着 分子としての機能や抗接着分子としての作用, さらには がん細胞の增殖に対する働き, 細胞性免疫や細胞の分化 に及ぼす影響，浸潤と転移に対する影響などが明らかに されつつある゙〉 また，上皮性腫瘍の多くがムチンを産 生することむよく知られており，その腫瘍生物学的意義 屯解明され始めている.ムチンの一次構造の解析に関し ては，その分子量が $5 \times 10^{2} \sim 3 \times 10^{4} \mathrm{kDa}$ と非常に大きい ことや糖を多量に含むことから，困難を極めていた。し かし，近年の遺伝子技術の発達之共に，様々なムチンに 対する解析がなされ，その一次構造が明らかにされつつ ある. 現在までに 9 種類が報告されており, 発見された

*岐皁大学農学部 (

** (現) 東京農業大学農学部（广243-0034 神奈川県厚木市船子 1737） 
順番に MUC1〜MUC8 (MUC5 は MUC5AC と MUC5 B）之呼ばれている。一方，ムチンの糖鎖構造に関しては 数多くの報告がなされている゙〉.その糖鎖は O-型が圧倒 的に多い，糖鎖の発揮する一部の機能は，糖銷の非還元 末端にグリコシド結合した状態で存在するシアル酸に よっている5). 例えば，インフルェンザなどのウイルス レセプター, 細菌性毒素のレセプター，免疫系における 細胞間認識, 腫瘍マーカー. 神経細胞の伸長などである。

オボムチン（OVM）もムチンに属し，卵白蛋白質の約 $3.5 \%$ を占め, ゲル状組織を構成している糖蛋白質であ る. その性状は電子顕微鏡による観察から絾維状であ り，2000 3000 nm の長さを示すとされている6). OVM の生体調節機能解析の研究はわずかであり”，さらには 乳中のムチンについても構造と生体調節機能の本格的な

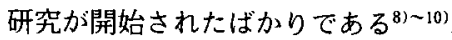

\section{(1) OVM の分子構造解析}

不溶型 OVM は $\alpha$-と $\beta$-サブュニットが $84: 20$ の割合 にて構成されている。この蛋白質は糖を 10 15\%含む $\alpha$-サブユーット（見かけ上の分子量 : $220 \mathrm{kDa}$ ）之糖を $50 \sim 65 \%$ 含む $\beta$-サブュニット（見かけ上の分子量 : 400 kDa）加ら構成された超巨大分子で，その分子量は光散 乱法により溶存型 OVMでは約 $8.3 \times 10^{3} \mathrm{kDa}$ ，不溶型 OVM では約 $2.3 \times 10^{4} \mathrm{kDa}$ と推定されている(11).12).

各サブユニットはジスルフィド結合を介して巨大分子 を形成している， $\alpha$-サブュニットは二量体にて存在し, それが $\beta$ サブュニットの重合体形成のためのジョイン トとして機能していること，OVMに部分的還元処理を 施した場合， $\alpha$ 之 $\alpha$ 及び $\alpha$ と $\beta$ 間の-SS-結合は後者の あのの方が特に切断されやすいことを証明した，OVM の Cys 残基のほとんどは遊離の-SH としてではなく， -SS-として存在していた.

OVM とその脱シアル化試料，或いは分画した各サブ ュニットのそれぞれは難溶性であるため,照濁した状態 にてプロナーゼあるいはトリプシンにて醉素分解し，可 溶性画分を得た。をれらの量, 化学組成 (アミ)酸と糖 組成，ならびに $\mathrm{N}$-末端加らの部分的アミノ酸配列）上 SDS-PAGE パターンを測定した．密集化した糖鎖及び -SS-結合の存在加蛋白質分解醉素にて処理しても，高 分子量の糖ペプチド或いはペプチドが残存した，各画分 をゲルろ過にかけ，精製したフラクションをさらに醉素 分解し，同様に分画後化学組成を解析した．これらの操 作の繰り返しにより, 各サブユーット内での糖ペプチド の配列を決定し, OVM のモデル構造を作成した (図 1). ß-サブュニットの分子中には O-型楉銷のみからなる糖
鎖の密集領域 $(60 \mathrm{kDa}, 120 \mathrm{kDa}$ と $100 \mathrm{kDa}$ のフラグメ ント)，及び N-とO-型糖鎖からなる糖鎖の比較的少な い領域とが交互に存在するとした， $\beta$-サブユニットの糖 鎖の多い領域のペプチドを構成するアミノ酸の種類は， 特定のアミ／酸に限定されていない，したがって，予想 されるOVMのアミ/酸配列の繰り返し構造は比較的多 種類のアミ/酸残基によっていよう

$\alpha$ サブユーットの遗伝子の単離と全塩基配列を決定 し，アミノ酸の一次構造の解析に成功した， N-末端を Lys とする全長にて 2087 個のアミ／酸残基から構成さ れている (塩基配列 : DDBJ, EMBL, and GenBank Databases/number AB046524)。 N-とC-末端領域は Cysに富み，相同性試験の結果七ト小腸ムチンMUC2 と高い相同性があると判明した，MUC2 とCys残基の 位置上の相同性が特に高かったが，MUC2 に存在する夕 ンデムリピートドメインは $\alpha$-サブュニットには存在し なかった (16) 17)

\section{（2）生体調節機能}

分画した各サプュニット，或いは酵素分解した可溶性 のフラグメントを用いて in vivo と in vitro 生体調節機 能を測定した．ウイルスに対する結合能と感染抑制作 用，抗腫瘍活性，脂質代謝改善作用（特に血清コレステ ロール降下作用)，ビフィズス菌・乳酸菌增殖作用につ き各フラグメントの特異性を認め, 分子構造と機能との 関係を明らかにしたＯOVM の糖蛋白質であるが故えの 難消化性に依存した消化器官内での食品機能が大いに期 待できよう。ここでは，抗ウイルス活性と抗腫場活性に ついて述べる.

i ）抗ウイルス活性

OVM はウシロタウイルス shimane 株, B 型インフル エンザウイルス A/Peking/352-89 株, ニューキャッス ル病ウイルス Ishii 株（NDV）に対する赤血球疑集阻害 活性, ならびにウイルスの細胞への感染阻止作用を有す るとしたＯOVMによるウイルスに対するそれらの作用 はいずれも含有楉銷がウイルスの一部と結合することに よると考えられるが，遊離の糖鎖ではなくぺプチドに固 定化した糖鎖の効果は大きい，OVMのフラグメント． サブュニットなどでウイルスに対する作用が異なり，特 異性を示した，その親和性が，OVMをプロナーゼ好理 することによって大きく減少した．このことは糖鎖ばか りでなくペプチドの関与も示すむのであった. 一方で は, 脱シアル化 OVM ではその親和性はほとんど消失し た．結局，大きな分子構造のシアル酸含有ペブチドが NDV に対する親和性を示すといえよう．このように， 
A $\alpha$-Subunit $\beta$-Subunit

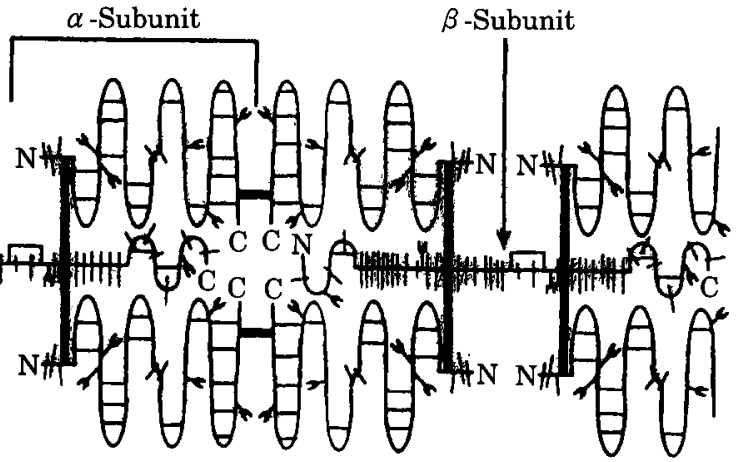

$\int$ 一段階還元処理

B

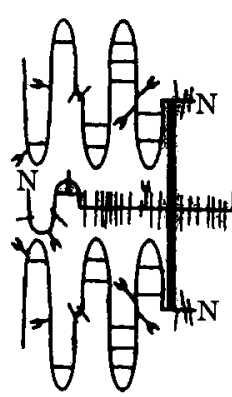

B
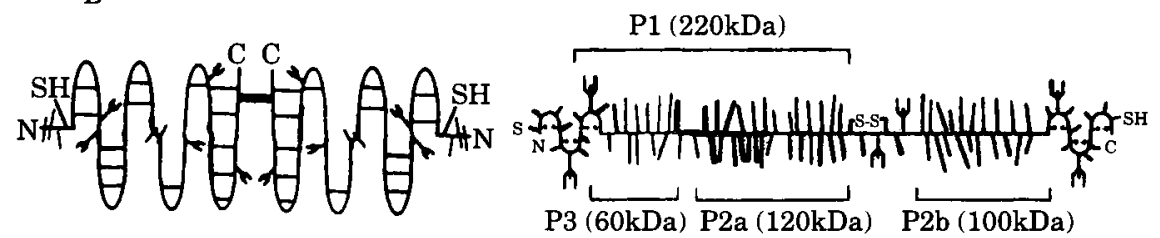

$\alpha$-Subunit dimer

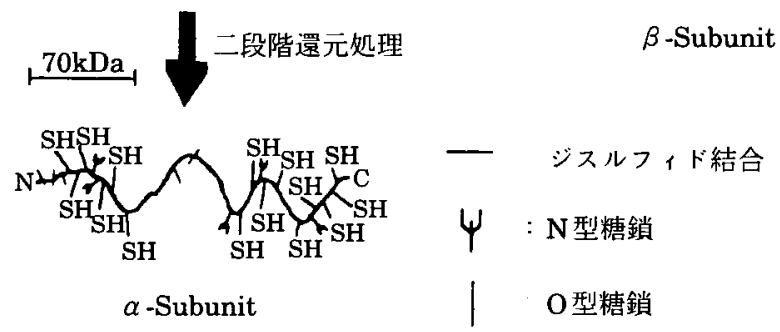

図 1 オボムチンのモデル構造

$\mathrm{A}: \alpha$-サブユーットと $\beta$-サブュニットの重合体構造

$\alpha$ が二量体にて $\beta$ の量体と-SS-結合にて結合し，この単位のものがさらに重合体を形成してゲル状を示 ఫ.

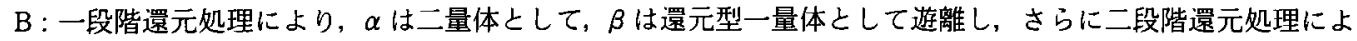
り， $\alpha$ は還元型一量体として遊離する.

OVMのウイルスに対する結合にはシアル酸がレセプ ターとして必須条件であることが示されたが, ペプチド 部分も間接的に関与していた.つまり，ペプチド上にゥ イルス親和性のある糖鎖の幾つかが結合することによ り，ウイルス膜上に突出するレセプターと数か所で結合 するこよができ, 糖鎖単独の場合よりはるかに結合がよ り安定であることを意味している(3)〜15).18), (9)

ii ) 抗腫瘍活性

一般に腫演細胞は脱分化した異型未分化細胞である.
これらの細胞は，正常な発生初期の未分化細胞に形態が 類似しているとされている，正常な未分化細胞は各生物 の胚発生時期の細胞にあたる.この時期の形態形成に関 与する細胞群は増殖率が高く，細胞分裂が顕著である. ヒョコへの睬化過程において急激な細胞分裂が生じる が，それらを制御する蛋白質が卵白に存在すると仮定し て探索し，OVMにその活性を認めた。

OVM のサブューット、或いはフラグメントを用いて, 細胞培養系とマウス二重移植腫愒系〔マウスの右側腹及 
び左側腹にそれぞれ $1 \times 10^{6}$ と $2 \times 10^{5}$ の同系腫瘍細胞を 皮内移植し (0日目)，3日目より3日間右側腫痬内に OVM 一定量投与, 21 日間飼育する」における抗腫痬活 性を認めた。 その機構として, 腫瘍細胞に対してネク ローシスを誘発する直接的傷害作用と間接的免疫賦活作 用を明らかにした。二重移植腫煬系の試験において，血 管新生阻害を主要な活性発現機構であると示した。固形 腫瘍の中でも悪性腫䀛は宿主血管を腫瘍内へ誘導し，血 管を発達させることにより，栄養物の供給と老廃物の排 泄を行い、さらに血液によりガス交換を行って増殖を続 ける，この際，腫瘍が血管新生因子を産生，放出する. OVM の血管新生阻止機構は血管内皮細胞の增殖と遊走 を阻止することによっていると示した．OVMが腫瘍と 内皮細胞などへの細胞増殖因子の取り込みを阻止してい るむのと考えられる201 27).

\section{2. 乾熱した卵白蛋白質の性状と食品物性改良剂 としての機能}

鶏卵の一次加工製品の一つに噴籍乾燥卵白 (SDEW) がある. その SDEW には製造後 Salmonella な゙の細菌 を死滅させるために, $55-63^{\circ} \mathrm{C} に て$ 数日間熱蔵庫に保管 するよいう熱蔵殺菌が施されている。このような殺菌し た SDEW の食品物性は, 殺菌前のものに比較して向上 していると食品工業界では経験的に知られている ${ }^{28)}$-30) このような背景のもとに，熱蔵殺菌した SDEW の食品 物性上の諸性質について，加藤ら ${ }^{31) \sim 33)}, \mathrm{Mine}^{34) \sim 36)}$ 及び 松富ら ${ }^{37)}$ の研究グループが科学的に解析するに至った。 彼等は，共通して，乾熱した卵白蛋白質に生じる微細な 構造変化に基づく可溶性凝集体の形成が，食品物性の向 上の鍵となっていると述べている。

一般的には，蛋白質の熱変性温度は水分含量が減少す るほど上昇する，筆者は，低水分含量下での熱処理によ る卵白蛋白質の性状変化と食品物性への影響に関心をも ち，新たに微水領域での高温での乾熱処理による卵白蛋 白質の性状につき解析した，SDEW 又は凍結乾燥した 卵白 (FDEW)，或いはオボアルブミン（OVA）とオボ トランスフェリン（OT）を用いて, 乾熱処理条件の設定 とその処理をした試料蛋白質の分子構造の変化及び食品 物性改良剤としての機能につき記述する。

（1）乾燥卵白に対する乾熱処理，及ひ乾熱卵白蛋白質 の諸性質

熱分析装置を用いて, 試料の乾熱中の重量変化を測定 した. 一定量の FDEWを $30^{\circ} \mathrm{C}$ から $150^{\circ} \mathrm{C}$ まで乾熱した 場合の水分含量の変化を測定した．最初のFDEW の水
分含量は $4.8 \%$ で，そのほとんどの水分は $60^{\circ} \mathrm{C}$ に至るま

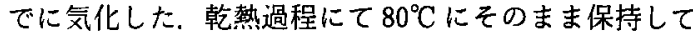
あ水分含量は低下せず，平衡状態上なった，さらに， $120^{\circ} \mathrm{C}$ まで昇温すると水分含量が $0.4 \%$ にまで減少し， その温度にて保持すると平衡状態となった。

一般的に, 乾燥蛋白質は $1 \mathrm{~g}$ 当たり $0.3 \sim 0.4 \mathrm{~g}$ の結合 水をむつとされている.この值は試料中の水分含量か 25\% 前後（多重層吸着水量として約 $15 \%$, 単分子層吸着 水量として約 $10 \%$ ）に相当する．これを OVA 1 モル当 たりに換算すれば，結合水が 800 モル前後（多重層吸着 水量が約 550 モル，単分子層吸着水量が約 250 モル）上 なる. 前述の乾燥時の水分含量をOVAの場合として計 算すると, OVA 1 モル当たり $4.8 \%$ にて約 250 モル, $3.5 \%$ にて約 87.5 モル，0.3\%にて約 7.5 モルの水分子か 残存することになる.これらより，FDEW にはほとんよ゙ 多重層吸着水が存在しない状態と推察される，さらに， 単分子層吸着水も乾熱時にもその温度に応じて気化して いると認められた。

そこで， $120^{\circ} \mathrm{C} に て 6$ 時間まで乾熱した FDEW を蒸 留水にて $10 \%$ 溶液とし，可溶性蛋白質量と濁度を测定 した，さらに，それらの溶液を $60^{\circ} \mathrm{C} ， 3.5$ 分加熱後, 同様 にそれらを測定した。 2 時間以上の乾熱時間に応じて， 凝固物の無い透明溶液が得られた，SDEW 試料とし て， $70^{\circ} \mathrm{C}$ から $130^{\circ} \mathrm{C}$ までの間にて様々な時間乾熱し，そ れらを前述と同様にして再加熱後の濁度を測定した。透 明溶液を得るのに, 乾熱温度が $70^{\circ} \mathrm{C}$ から $90^{\circ} \mathrm{C}$ 至る温 度では 25 時間以上要したが, $105^{\circ} \mathrm{C}$ 以上ではその時間が 大きく短縮され数時間となった。このようにして, $105^{\circ} \mathrm{C}$ 付近に一つの屈曲点があり，乾熱温度が高いほよ゙，すな わち，単分子層吸着水の少ないほど短時間加熱によって 溶解度が良く，しかも透明度の高い溶液上なる乾熱卵白 が調製できた。

乾燥した各種卵白蛋白質の溶解度，凝集性と分子構造 の変化を測定した. SDEW, OVA，OT，或いはOVAと OT の混合物（OVA-OT）を $120^{\circ} \mathrm{C}$ にて 6 時間まで乾熱 した〔乾熱試料をそれぞれ DHSDEW，DHOVA， DHOT, DH (OVA-OT) とする]。これらを $10 \%$ 溶液と して再溶解すると, DHSDEW，DHOVA とDH (OVAOT）では溶解度を失うことなく，部分的可溶性凝集体の 形成をみた。一方，DHOTでは乾熱時間が長くなるにつ れて不溶化し，6時間の乾熱では溶解度が $40 \%$ 以下にま で低下した，DH (OVA-OT) 系において, PAGE, SDS -PAGE と HPLC により, DHOVA とDHOT が相互作 用し, DHOVAの DHOT に対する保護作用により再溶 
解時にあ見かけ上溶解度が保たれていると結論した，可 溶性凝集体は, SDS 及び還元剤の存在下においてもその 構成単量体に解離せず, 強固な相互作用にて会合してい るものとした，また，HPLC-光散乱計の分析により，乾 熱した卵白蛋白質の粒子量は凝集化して幅の広い分布を しているが，単量体分子もかなり残存しているため，平 均粒子量, 粒子半径共にそれほど大きくは変化していな いという結果が得られた $\left(120^{\circ} \mathrm{C}, 6\right.$ 時間乾熱処理にても 单量体を主体としているが，最大でほぼ 10 量体以下の 凝集体を形成している，凝集体む大きくなるほよ゙微量と なる ${ }^{38)-40) . ~}$

蛋白質の変性は，未変性状態と変性状態の二つの状態 だけが存在し，両者に平衡が成立しているような二状態 転移で近似できる場合も多いが, 変性過程がいくつかの 中間状態（モルテングロビュール状態: 二次構造はかな り保持されているが，三次構造は失われている．コンパ クトな状態にあり，大きさは未变性蛋白質とほぼ同じで ある. 非極性領域が多く露出していて，疎水性相互作用 により凝集しやすい）を経て進行する場合す知られてい る. 未変性 OVA の変性温度 $81^{\circ} \mathrm{C}$ であるのに対して, 6 時間乾熱した DHOVA では，再溶解後 $50^{\circ} \mathrm{C}$ 前後から一 部の分子が変性・凝集化し， $60^{\circ} \mathrm{C} ， 3.5 \sim 5$ 分加熱におい て可溶性凝集体（粒子量が最大約 100 万の会合体を主体 とし，3〜5量体以下の小さい凝集体む存在した）を生成 しているとした. CD 测定及び ELISA 法と免疫定量沈 殿反応法によって測定したDHOVAと抗OVA 抗体と の反応性から，乾熱時間が長くなるにつれて OVA 分子 の構造がわずかに unfolding（モルテングロビュール様 状態)していること，及び DHOVA の熱変性温度はより 低下していることを明らかにした．乾熱によって凝集化 した可溶性凝集体の存在が特に注目されがちであるが, $120^{\circ} \mathrm{C}$ で 6 時間の乾熱によってもなお残存する単量体分 子の再加熱時の溶液中における変性温度の低下上それに 基づく相互作用の挙動が重要であるとした，DH（OVAOT）の溶液を $60^{\circ} \mathrm{C}, 3.5$ 分加熱すると, 最大約 200 万の 会合体を形成し，3～5 量体の凝集体も存在することも認 めた。これに対して，乾燥卵白蛋白質を同様に加熱好理 すると，OT 間のランダム会合体の形成による白濁の沈 殿物形成となった．高粒子量可溶性凝集体はこれまで線 状凝集体であるとされてきたが，乾熱した単量体，二量 体上三量体の凝集物が互いに $60^{\circ} \mathrm{C} ， 3.5$ 分加熱において 線状及びランダムの混合した状態にて会合すると推测し た。乾熱した試料では，ランダムの会合が主体の未乾熱 試料と比較した場合，その大きさが小さくコンパクトと
なっている点に特徵があるとしだ1).

（2）乾熱卵白蛋白質の新鮮卵白に対する熱凝固阻止 作用

生卵白を $60^{\circ} \mathrm{C} ， 5$ 分加熱すると生卵白に一部凝固物が 形成されるが，生卵白に DHSDEW の $10 \%$ 溶液を添加 して加熱すると，凝固物形成が抑制されると分かった。 DHSDEW 中の DHOVA の単量体或いは可溶性凝集体 が，生卵白中の OT との分子間相互作用して，OT 間の 凝固形成が阻止されていると推測した。 DHOVA と未乾 熱 OT のそれぞれの 10\% 溶液を $1: 1(\mathrm{~V} / \mathrm{V})$ に混合し， $60^{\circ} \mathrm{C}$ で 5 分間再加熱した。乾熱時間が長くなるにつれ て，沈殿物の無い透明溶液となった。これは，再加熱時 に変性したOTによる OTーOT 間の凝固物形成が，部分 的に変性した DHOVA とOT 問の相互作用により阻止 されることに依存していると結論した。生卯白と DHSDEW 混合系の熱殺菌後の泡立ちとゲル化力は良好 であった.

（3）乾熱卵白蛋白質ゲルの特性

DHSDEW 或いは DHOVA を溶解後, 再加熱 $\left(80^{\circ} \mathrm{C}\right.$, 15 分）してゲルを形成させ，それらのゲルの破断強度， クリープとテクスチャー解析を行った. SDEW 或いは OVAのゲルに対する乾熱試料のゲル品質の良さが有意 な差をむって示された，次に，DHOVA 溶液の熱処理時 の動的粘弾性を測定したところ，DHOVA 溶液ではゲル 化開始温度む低下し，弾性・粘性面にて共に高いゲルと なった．より低温にてゲル化が開始している点が品質の 良さの一要因となるとした。乾燥及び乾熱卵白蛋白質溶 液を $\mathrm{NaCl}(1 \%$ 上 $3 \%)$ の存在の下に $80^{\circ} \mathrm{C} ， 15$ 分加熱処 理して得たゲル化を走査電子顕微鏡にて観察すると，乾 燥卵白系では大きなランダムな会合体 $(0.01 \mu \mathrm{m}$ 前後の 粒子が会合して, 粒子の大きさがぼぼ $0.3 \mu \mathrm{m}$ となって いる， $\mathrm{NaCl}$ の添加により粒子が大きくなる）となるに 対して, 乾熱卵白系では, 線状凝集体とランダム球状凝 集体が混合した形態をとっているが，小さくコンパクト な網目構造を示した $(0.01 \mu \mathrm{m}$ 前後の会合体の形成が あった).このように, 乾熱試料ではネットワーク構造の 網目の大きさが小さいと分かった．ランダム凝集体の形 成の度合いが異なり，乾燥卵白蛋白質系の方が，乾熱卵 白蛋白質よりあランダム凝集体の割合が高い．末乾熱試 料からのゲルでは大きな隚間が多く見られ，保水性が低 いと思われた．それに対し DHEW とDHOVAからのゲ ルは，均一で目の細かい網目構造を形成し，隙間の少な いゲル構造をしていた。

乾熱試料を溶解後, $60^{\circ} \mathrm{C}$ にて予備加熱し， $80^{\circ} \mathrm{C}$ にてゲ 
噴靁乾燥卵白の加熱ゲル

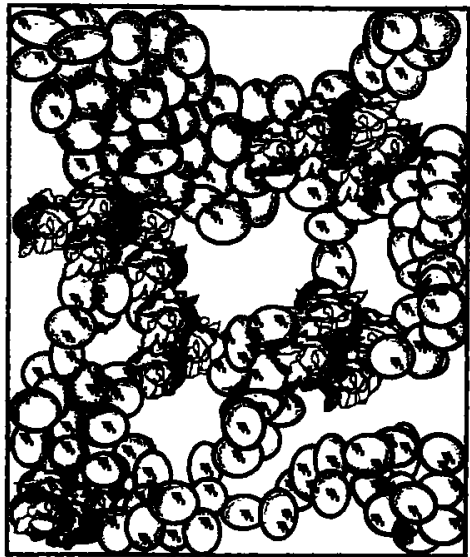

乾熱卵白の加熱ゲル

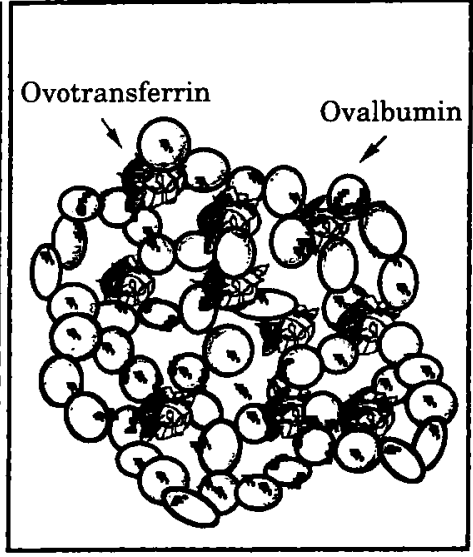

図 2 噴霧乾燥卵白及びその乾熱卵白の加熱ゲルの構造

噴霧乾燥卵白の加熱ゲル：OT（オボトランスフェリン）の重合体とOVA（オボアルブミン）の重合 体の相互作用による加熱ゲル.

乾燥卵白の加熱ゲル：OT とOVA の相互作用による加熱ゲル.

ル化させるとゲル強度が約 1.5 倍上昇すると分かった。

より低温での蛋白質間での相互作用に依存するものと理 解される。これらより，蛋白質溶液を加熱処理してゲル 化させる場合に，一段階反応としての小さい粒子が形成 され，それが二段階反応として会合して大きな粒子とな ると考えた。

以上の成果に基づき, SDEW と DHSDEW からのゲ ルをモデル的に図式化した（図 2). 乾熱の有無は, OTOT 間の凝集体とOVA-OVA 間の凝集体のそれぞれが 会合したゲルと，OVA-OT 間という異種蛋白質間の凝 集体が会合したゲルという差異に特徵があると結論し た.

DHSDEW 系とDHOVA 系での $\mathrm{NaCl}$ の影響の受け 方に差異がみられた，前者では $\mathrm{NaCl} の$ 存在なしにて加 熱に際してゲル化したのに対して，後者では $\mathrm{NaCl}$ の存 在なしではゲル化は不十分であった， $\mathrm{NaCl}$ の添加なし の系において，DHSDEW を加熱すると，SDEW の場合 よりも 10 倍程度のゲル強度を示した。

\section{（4）乾熱卵白の食品物性改良刘としての機能}

DHSDEW をソーセージ, 練り製品, 麺類に添加して, それらの製品を食品工業レベルのモデル系において製造 した，従来の乾熱卵白添加製品を対照にして，有意な差 をむって食品物性（ゲル強度，保水性等）の改良と良好 な官能試験結果が得られた。これすDHSDEW 中の OVA の熱変性温度の低下に伴うゲル化力向上と他の蛋
白質との相互作用によると結論した。

このように，乾熱卵白蛋白質を利用した多種類の加工 食品の物性改変が可能であった。

ここに述べた研究成果は，岐阜大学農学部において最 近行ったものである. 名古屋大学農学部時代に永年にわ たってご指導をいたたきました恩師故佐藤 泰先生, 中 村 良先生に厚く御礼申し上げます，また，共同研究者 としてご協力いただきました多数の方々には深甚の謝意 を表します。

\section{文献}

1）渡邊乾二：日農化誌，74,802（2000）

2) Neutra, M.P. and Forstner, J.F. : in "Physiology of the Gastrointestinal Tract," 2nd Ed., ed. by Johnson L.R., Raven Press, New York, p 975, (1987).

3) Makiguchi, Y., Hinoda, Y. and IMaI, K. : Jpn. j. Cancer Res., 87, 505 (1996).

4) GuM, J.R. Jr.: Biochem. Soci. Trans., 23, 795 (1995).

5) Pilatte, Y., Bignon, J. and Lambre, C.R. Glycobiology, 3, 201 (1993).

6) Rabouille, C., Aon, M.A., Muller, G., Cartaud, J. and Thomas, D. : Biochem. J., 266, 697 (1990).

7) Tamizaki, H., Tanaka, H., Iwata, H. and Kato, A. : Biosci. Biotechnol. Biochem., 61, 1883 (1997). 
8) Yolken, R.H., Peterson,J. A., Vonderfecht, S. L., Fouts, E.T., Midthun, K. and Newburg ,D.S. : J. Clin. Invest., 90, 1984 (1992).

9) Kanamaru ,Y., IKeda, S., YanG, S-M., Kaneko , T., Kuwata, T., NagaoKa,S., ShimizU, M. and Sachdev, G. P. : Biochem. Biophys. Res. Commun., 249, 618 (1998).

10) Patton, S. : J. Dairy Sci., 82, 1115 (1999).

11) Hayakawa and ,S. Sato, Y. : Agric. Biol. Chem., 41, 1185 (1977).

12) Kato, K., Oda, S., Yamanaka, Y., Matsudomi, N. and KobaYAshi,K. : Agric. Biol. Chem., 49, 3501 (1985).

13) Tsuge, Y., Shimoyamada, M. and Watanabe, K. : J. Agric. Food Chem., 45, 2393 (1997).

14) Tsuge, Y., Shimoyamada, M. and Watanabe, K. : J. Agric. Food Chem., 45, 4629 (1997).

15) Watanabe, K. Tsuge, Y. and Shimoyamada, M. : J. Agric. Food Chem., 46. 4501 (1998).

16) Gum, J.R., Hicks, J.W., Toribara, N.W., Rothe, E.M., LAGACE,R.E. and KIM, Y.S. : J. Biol. Chem., 267, 21375 (1992).

17) Gum, J.R., Hicks, J.W., Toribara, N.W., SiddikL, B. and KIM, Y.S. : J. Biol. Chem., 269, 2440 (1994).

18) Tsuge, Y., Shimoyamada, M. and Watanabe, K. : Biosci. Biotechnol. Biochem., 60. 1503 (1996).

19) Tsuge, Y., Shimoyamada, M. and Watanabe, K. : Biosci. Biotechnol. Biochem., 60. 1505 (1996).

20) Watanabe, K., Tsuge, Y. Shimoyamada, M., Ogama, N. and Ebina, T. : J. Agric. Food Chem., 46, 3033 (1998).

21）大網 弘・大石一二三・横田 隆 - 森隆 $\cdot$ 渡 邊乾二 : 医学々生物学, 126, 19 (1993).

22) Yokota, T., Ohishi, H. and Watanabe, K. : Food Sci. Technol. Res., 5, 273 (1999).

23) Yokota, T., Ohishi, H. and W atanabe, K. : Food Sci. Technol. Res., 5, 279 (1999).

24) Yokota, T., Tani, H., OHishi,H., Oguro, T. and WatANABe, K. : Food Sci. Technol. Res., 6, 275
(2000).

25) Oguro, T., Watanabe. $\mathrm{K}, \mathrm{T}$ ani, $\mathrm{H}$., Ohishi, $\mathrm{H}$. and EBINA, T. : Food Sci. Technol. Res., 6, 179 (2000).

26）小黑辰夫 - 大秋美治 - 浅野伍朗 - 海老名卓三郎 渡邊乾二 : 臨床電顕誌, 33, 89（2001）。

27）小黑辰夫 - 大秋美治・浅野伍朗・海老名卓三郎・ 渡邊乾二：臨床電顕誌, 33, 131（2001）.

28) Banwart, G. and Ayres, J.C.: Food Technol., 10, 68 (1956).

29) Baldwin. R.E., Cotterill, O.J., Thompson, M.M. and Myers, M. : Poultry Sci., 46, 1421 (1967).

30) Bergquist, D.H. : U.S. Patent, 2, 982, 663 (1961).

31) Kato, A., Ibrahim, H.R., Watanabe, H., Honma, K. and Kobatashi, K. : J. Agric. Food Chem., 37, 433 (1989).

32) Kato, A., Ibrahim, H.R., Watanabe, H., Honma, K. and Kobayashi, K. . J. Agric. Food Chem., 38, 32 (1990).

33) KATO, A., IBRAHIM, H.R., TAKAGI, T. and Kobayashi, K. : J. Agric. Food Chem., 38, 1868 (1990).

34) Mine, Y.: Trend in Food Sci. \& Technol, 6, 225 (1995).

35) Mine. Y, : Food Res. Int., 29, 155 (1996).

36) Mine. Y. : J. Agric. Food Chem., 45, 2924 (1997).

37) Matsudomi, N., Ishimura, Y. and KATo, A. : Agric. Biol. Chem., 55, 876 (1991).

38) XU, J.Q., Shimoyamada, M. and Watanabe, K. J. Food Sci., 62, 963 (1997).

39) XU, J.Q., Shimoyamada, M. and Watanabe, K. : J. Agric. Food Chem., 46, 3027 (1998).

40) Watanabe, K., Xu, J.Q. and Shimoyamada, M. : J. Agric. Food Chem. 47, 4083 (1999).

41 Watanabe, K., Nakamura, Y., XU, J.Q. and Shimoyamada, M. .J. Agric. Food Chem., 48, 3965 (2000).

(平成 13 年 4 月 13 日受理) 